\title{
A Hister Beetle Carcinops pumilio (Erichson) (Insecta: Coleoptera: Histeridae: Dendrophilinae: Paromalini) ${ }^{1}$
}

\author{
Matthew R. Moore and Phillip E. Kaufman²
}

\section{Introduction}

The hister beetle Carcinops pumilio (Erichson) is a predator and natural enemy of the pestiferous house fly, Musca domestica Linnaeus (Figure 1). Carcinops pumilio has a broad world distribution and is associated with wild bird nests and bat guano piles. This species' ability to limit house fly populations in poultry production settings led to its study as an augmentative biological control agent (Bills 1973; Kaufman et al. 2002a, 2002b; Achiano and Giliomee 2005).

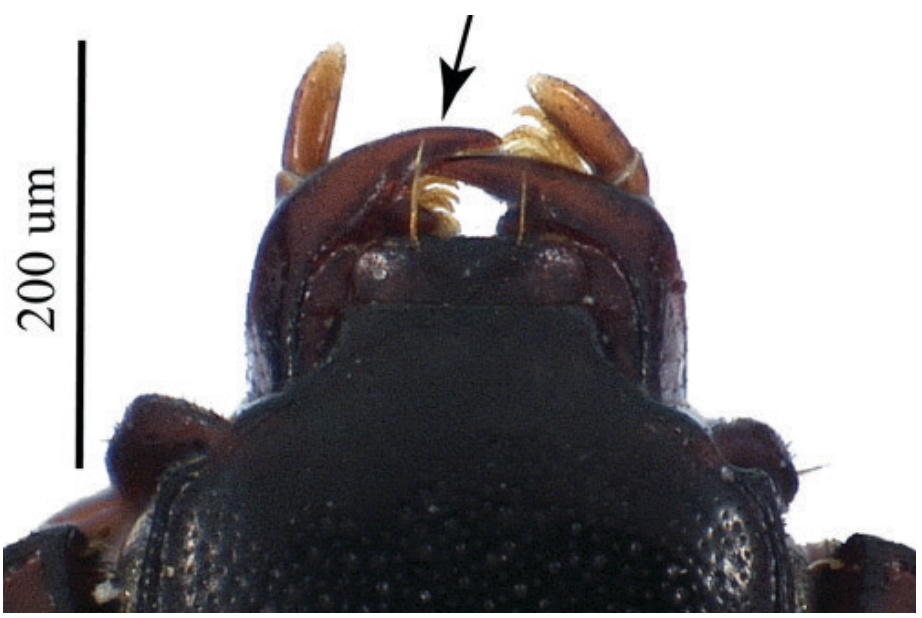

Figure 1. Dorsal view of the head of an adult Carcinops pumilio. The arrow indicates the large, sickle-shaped apex of the mandibles. Credits: Matthew R. Moore, UF/IFAS

\section{Taxonomy and Synonymy}

The taxonomic history of this hister beetle is complicated and marked by confusion of the scientific names Carcinops pumilio (Erichson) and Carcinops quattuordecimstriata (Stephens) that stems from uncertainty surrounding the publication dates of these. Carcinops pumilio was originally described in the genus Paromalus from a series of specimens collected in Spain, North America, and Egypt (Erichson 1834). The species was transferred to the new genus Carcinops by Marseul (1855), and the classification of the species in the genus Carcinops was accepted by most subsequent historical authors (Marseul 1862; Gemminger and Harold 1868; Ganglbauer 1899; Lewis 1905; Reitter 1909; Kolbe 1910; Scott 1913; Bickhardt 1910, Bickhardt 1917; Blackwelder 1944).

However, Stephens's (1835) name Carcinops quattuordecimstriata, described from England and referring to the same organism, was considered the senior synonym (i.e., it was thought to be the older name) and the valid name for the species because it was thought to have been described before Carcinops pumilio (Erichson). Stephens's (1835) book was published in parts, at separate times, but was labeled as being published in 1832 (see Méquignon 1944; Blackwelder 1949). The pages where Carcinops quattuordecimstriata was described were in fact printed in 1835 (Méquignon 1944; Blackwelder 1949). Once this historical error was discovered, Carcinops pumilio was considered the

1. This document is EENY673, one of a series of the Department of Entomology and Nematology, UF/IFAS Extension. Original publication date February 2017. Visit the EDIS website at http://edis.ifas.ufl.edu. This document is also available on the Featured Creatures website at http://entnemdept.ifas.ufl. edu/creatures/.

2. Matthew R. Moore; and Phillip E. Kaufman, associate professor; Department of Entomology and Nematology, UF/IFAS Extension, Gainesville, FL 32611.

The Institute of Food and Agricultural Sciences (IFAS) is an Equal Opportunity Institution authorized to provide research, educational information and other services only to individuals and institutions that function with non-discrimination with respect to race, creed, color, religion, age, disability, sex, sexual orientation, marital status, national origin, political opinions or affiliations. For more information on obtaining other UF/IFAS Extension publications, contact your county's UF/IFAS Extension office. 
valid scientific name for this hister beetle. A summarized list of synonyms of Carcinops pumilio (Erichson) is given below (following Mazur 1997; Bousquet and Laplante 2006; Lackner et al. 2015).

Paromalus pumilio (Erichson, 1834)

Dendrophilus pumilio (Erichson, 1834)

Dendrophilus 14-striatus (Stephens, 1835 )

Carcinops 14-striatus (Stephens, 1835)

Carcinops quatuordecimstriata (Stephens, 1835)

Dendrophilus quattuordecimstriatus (Stephens, 1835)

Paromalus quatuordecimstriatus (Stephens, 1835)

Hister nanus (LeConte, 1845 )

Phelister nanus (LeConte, 1845)

Epierus krujanensis (Mader, 1921)

\section{Distribution}

Carcinops pumilio has a broad world distribution (Figure 2 and Table 1). The association of these beetles with domestic poultry (e.g., chickens and turkey) possibly contributed to their spread across the globe (Legner and Olton 1970). These beetles are also found in the nests of wild birds.

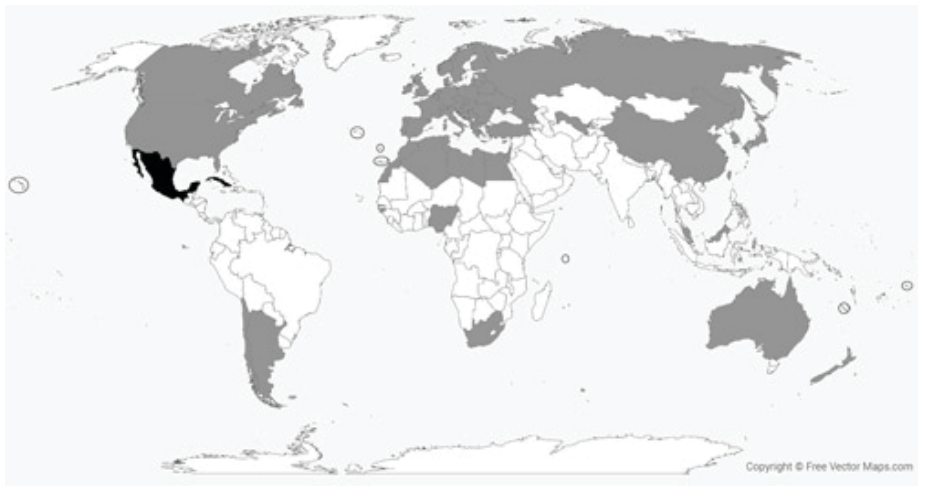

Figure 2. Global distribution of the hister beetle, Carcinops pumilio (Erichson). Data are presented at the country-level. Occurrences in solid gray are based on published data from the literature or museum specimen databases. Occurrences in black (Cuba and Mexico) are based on speculation in the literature and online checklists. Grey circles surround the Madeira Archipelago, Azores, Canary Islands, Samoa, Hawaiian Islands, and Seychelles.

Credits: Matthew R. Moore, UF/IFAS; (vector map of the world provided for free by freevectormaps.com (WRLD-EPS-01-0013))

\section{Description}

Carcinops pumilio is a holometabolous insect and thus undergoes complete metamorphosis (egg-larva-pupaadult). Below are descriptions of the life stages of Carcinops pumilio.

\section{Eggs}

Eggs of Carcinops pumilio are elongate and oval. The ends taper, and they have an overall white or cream color (see Achiano and Giliomee 2005 for images of eggs). Completely developed eggs are small. Eggs range from $0.65 \mathrm{~mm}$ to 0.92 $\mathrm{mm}$ in length (Geden and Stoffolano 1987).

\section{Larvae}

Larvae newly emerged from the egg are cream-colored, but the head is brown (Achiano and Giliomee 2005). Second instar larvae are about twice as large as the first instar larvae (Achiano and Giliomee 2005) (Figure 3).

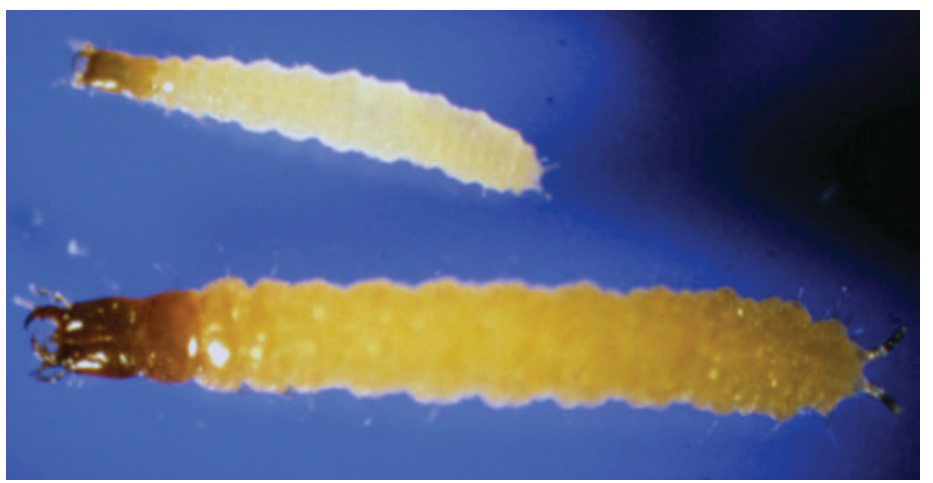

Figure 3. First instar (top) and second instar (bottom) larvae of the hister beetle, Carcinops pumilio.

Credits: Phillip E. Kaufman, UF/IFAS

\section{Pupae}

Exarate pupae (pupa with free antennae, wings, and legs) are initially white but later darken to brown and black before adult emergence (see Achiano and Giliomee 2005 for images of pupae).

\section{Adult}

Adult Carcinops pumilio are small beetles that vary in total length from 1.6-2.7 mm (Hinton 1945). These black beetles have an oval shape and a glossy cuticle while the legs can be brownish-red (Hinton 1945) (see Figure 1). Carcinops pumilio typically has 14 total (7 on each elytron, or wing cover) striations (impressed lines composed of punctures) on the wing covers (Figure 4). 


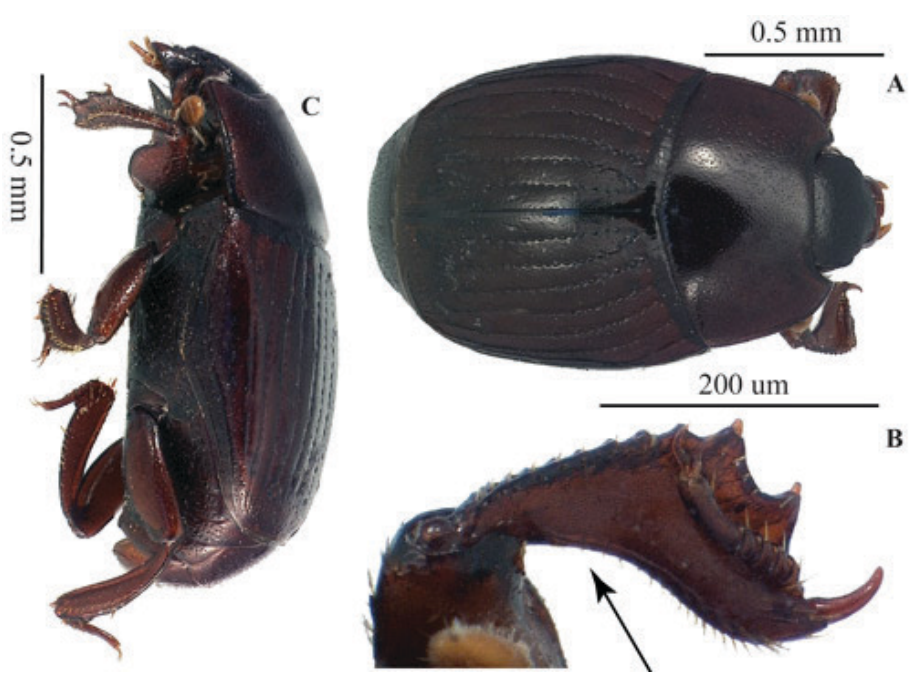

Figure 4. Carcinops pumilio, adult specimen. A) View from

above. B) Front tibia of the adult. The arrow indicates the characteristic arcuate (curved, bow-like) shape of the front tibia in Carcinops pumilio. C) View from the side.

Credits: Matthew R. Moore, UF/IFAS

\section{Life Cycle}

Laboratory rearing techniques for Carcinops pumilio were investigated due to these beetles' potential use as biological controls of flies in manure. Experiments and observational studies have provided detailed information about the life cycle of Carcinops pumilio. Carcinops pumilio go through two larval development stages (instars) (Linder 1967; Achiano and Giliomee 2005). Laboratory studies indicate that adult Carcinops pumilio will eat an average of 13 house fly eggs per day (Morgan et al. 1983), but this could be an underestimate based on Geden and Axtell (1988) (see section on Economic Importance).

Females average 1.8 egg-laying events per day in the lab, but the timing between egg-laying is variable from one to three days (Morgan et al. 1983). Some females can lay eggs from 5 to 12 consecutive days (Morgan et al. 1983). Multiple studies have examined developmental rates of Carcinops pumilio (Morgan et al. 1983; Fletcher et al. 1991). At $25.5^{\circ} \mathrm{C}$, embryo development within eggs is completed from 2 to 11 days with an average of 6.2 days (Morgan et al. 1983). The larval stage lasts for an average of 15.5 days (Morgan et al. 1983). The pupal stage lasts for an average 17.5 days (Morgan et al. 1983). Total development time from egg to adult is slightly longer for females (42.3 days on average) than males (40 days on average) (Morgan et al. 1983). Fletcher et al. (1991) found a shorter total development time of 34.1 days on average at $25.5^{\circ} \mathrm{C}$. The shortest mean total development time of 16.9 days occurred at $32.5^{\circ} \mathrm{C}$ (Fletcher et al. 1991). Adult beetles can live for up to two to three years (Linder 1967).

\section{Ecology}

Carcinops pumilio beetles are predators of fly eggs and larvae (Figure 5). In natural areas, these beetles have been found in various types of moist organic detritus (wet and decaying plant matter, animal carrion, and animal/ human feces) where they can find their immature fly prey (Ganglbauer 1899; Bousquet and Laplante 2006; Bajerlein et al. 2011; Borowski and Mazur 2015). Carcinops pumilio have been collected from bird nests and near bat roosts. They have also been collected from the carcasses of birds (Bryan 1926). Data for bird nest associations of Carcinops pumilio are summarized for North America (Table 2) and Europe (Table 3).

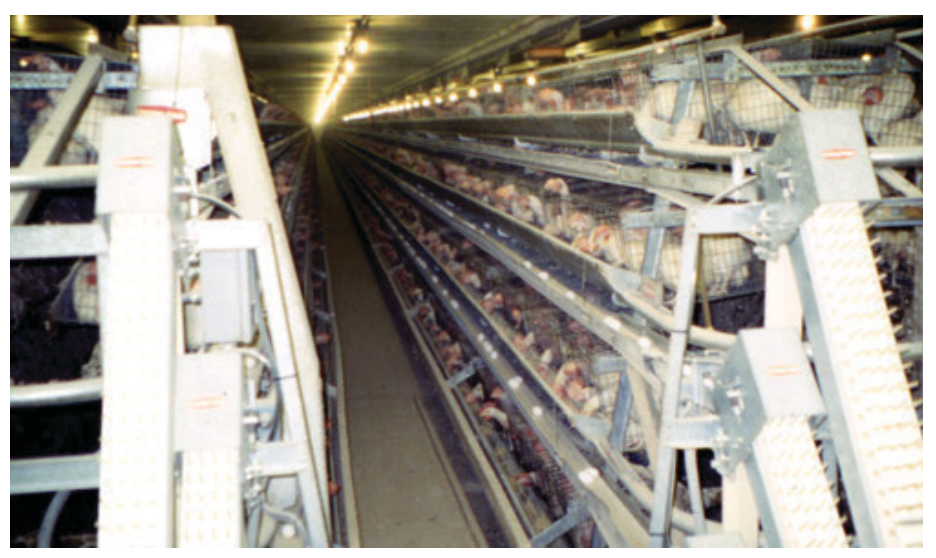

Figure 5. An example of a caged-layer poultry cage. Credits: Phillip E. Kaufman, UF/IFAS

Carcinops pumilio has been collected from guano piles of the evening bat (Nycticeius humeralis [Rafinesque]) and the little brown bat (Myotis lucifugus [LeConte]) (Bernath and Kunz 1981; Whitaker et al. 1991). These beetles can be found near the University of Florida bat houses (Tishechkin 2010a), which serve as roosts for several species of bats (Brazilian free-tailed bats, Tadarida brasiliensis cynocephala [LeConte]; southeastern mouseeared bats, Myotis austroriparius [Rhoads]; evening bats) (FLMNH 2016). Carcinops pumilio has been collected from underneath tree bark (Arrow 1927) and from inside the terminal shoots of beetle-damaged coniferous trees (Taylor 1928), suggesting dietary or habitat diversity.

\section{Economic Importance}

As a biological control agent, Carcinops pumilio has attracted research attention due to its voracious appetite for fly pests of poultry production. Research has focused on this hister beetle's life cycle, dietary preferences, ability to disperse as adults, and how it fits into various integrated pest management (IPM) regimes. Carcinops pumilio is considered an important biological control agent of house 
flies (Musca domestica Linnaeus) in caged-layer poultry houses (Figure 6 and Figure 7).

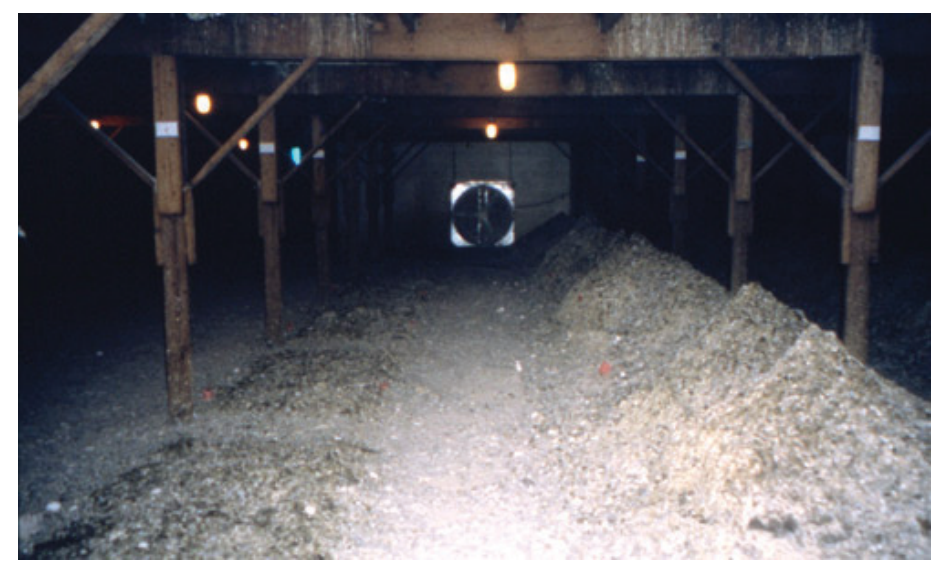

Figure 6. Manure pit underneath cage-layer poultry house. The left row of manure has been recently removed. The right row shows poultry manure accumulation.

Credits: Phillip E. Kaufman, UF/IFAS

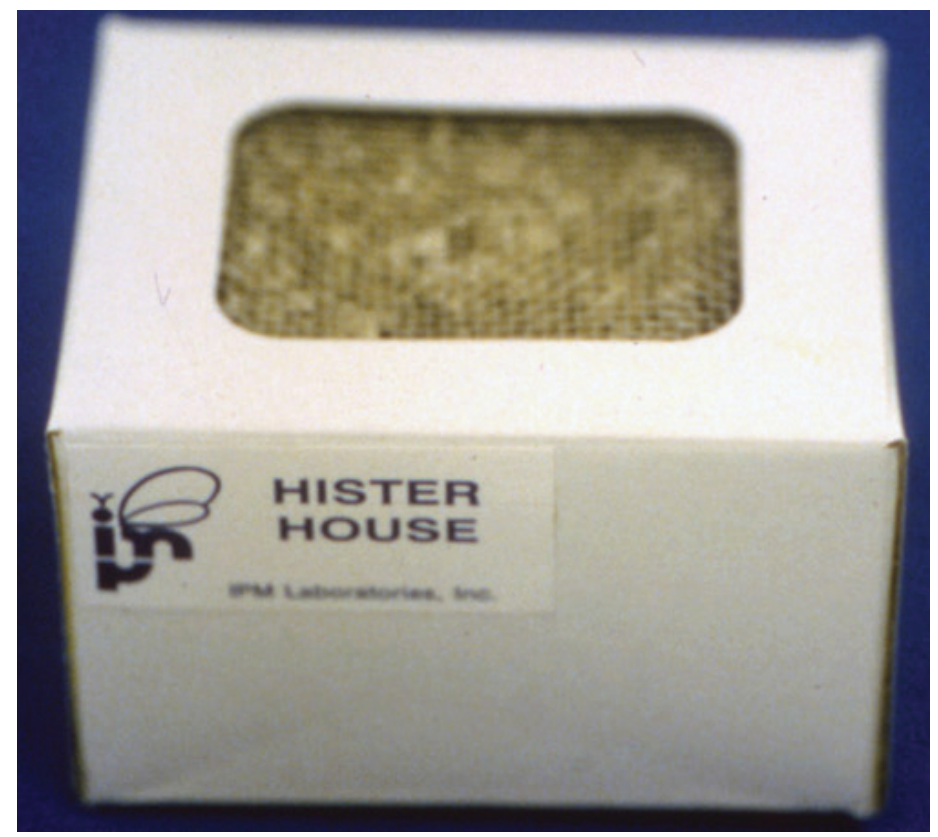

Figure 7. Attractant-based Hister House trap. Carcinops pumilio are attracted to the bait and enter through the screen on the trap, which is placed in contact with the manure. The screen is fine enough to exclude the omnivorous lesser mealworm, Alphitobius diaperinus (Panzer)

Credits: Phillip E. Kaufman, UF/IFAS

Modern, high-density poultry production results in the buildup of manure in pits underneath hen cages. Accumulated manure can be stored for long periods depending on the style of the cage unit used by producers (Figure 7). For example, South African poultry producers can allow manure to accumulate for 2-3 years underneath two-storied cage units before the collection pit is cleaned out (Achiano and Giliomee 2006a). These conditions are excellent for fly development if manure moisture is not minimized.
House flies are the major pest of high-density caged-layer poultry production. In this system, house flies will lay their eggs on the accumulating manure. This is particularly problematic after manure removal has occurred when newly accumulating manure remains very wet. Compounding the challenge of large numbers of eggs being laid are that biological control agents are limited in abundance, largely having been removed with the manure during cleanout. Without proper management (introduced biological control or pesticide applications), fly populations can reach pestiferous levels within two or three weeks. When adult house fly numbers are high, a portion of the fly population may disperse from the poultry facility and accumulate at nearby residential areas, potentially causing conflict at this agricultural-urban interface. To prevent this occurrence, poultry producers actively manage the manure accumulations, including the proactive use of biological control agents such as purchased parasitoid wasps and the within-farm transfer (between poultry buildings) of Carcinops pumilio.

A single Carcinops pumilio individual can consume over 100 fly eggs and maggots per day depending on temperature (Geden and Axtell 1988). These beetles are considered effective biological control agents of flies in poultry production due to their high rate of fly predation. Manure pit conditions, such as temperature, the age of manure, and manure water content, can influence whether these hister beetles can establish.

All life stages of Carcinops pumilio can be found in poultry manure with moisture content between 55\% and 80\% (Achiano and Giliomee 2006a). First instar larvae are more common in manure with a $55 \%$ to $60 \%$ moisture content (Achiano and Giliomee 2006a). Second instars and adult beetles are more common in manure with moisture contents between 70\% and 75\% (Achiano and Giliomee 2006a). These beetles are commonly encountered in manure pits between $21^{\circ}$ and $27^{\circ} \mathrm{C}$ (Achiano and Giliomee 2006a). Poultry producers can enhance populations of Carcinops pumilio by keeping manure pits relatively dry and free from sources of excess water (Bills 1973; Achiano and Giliomee 2006a).

Studies have examined whether various IPM regimes for control of house flies can negatively affect beneficial Carcinops pumilio. For example, poultry houses treated with Beauveria bassiana (a fungal pathogen of house flies) were better able to maintain their populations of Carcinops pumilio versus those treated with pyrethrin-based insecticides for control of house flies (Kaufman et al. 2005). Poultry producers sometimes capture Carcinops pumilio in 
their facilities and move them to areas where they are absent or in low numbers.

Black-light trapping (better from March to June) and attractant-based traps (better from June to August) are both effective for collecting Carcinops pumilio for this purpose (Kaufman et al. 2002a, b) (Figure 8). However, beetles collected with attractant-based traps may be in better condition than those collected with black-lights (Kaufman et al. 2001a). Populations of Carcinops pumilio augmented with attractant-based traps collected individuals that will likely grow more quickly than those augmented with black-light trapped individuals (Kaufman et al. 2001a). Black-light captured Carcinops pumilio are hypothesized to be in a state of active dispersal away from an area due to high beetle density or lack of prey and may not stay in the area where released (Kaufman et al. 2000).

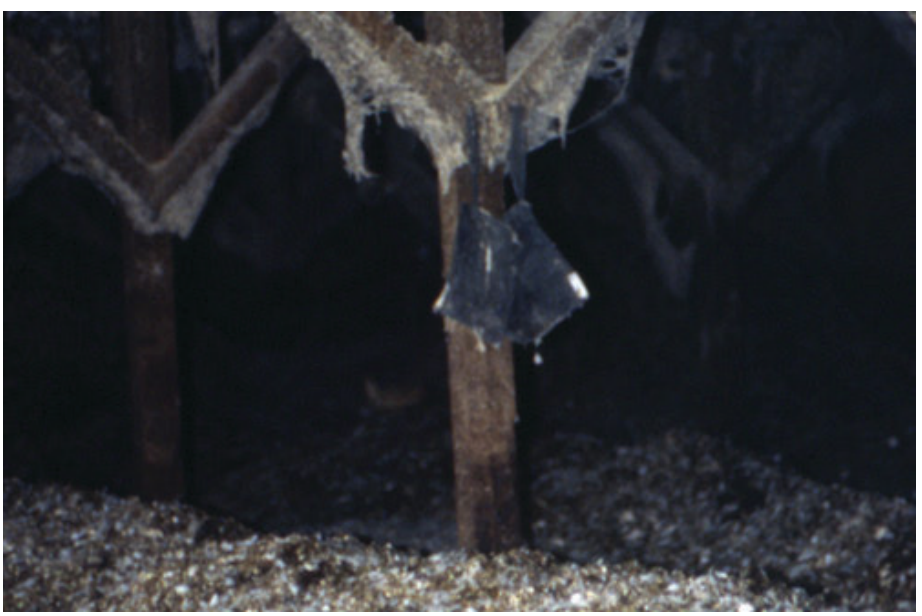

Figure 8. Manure pit under a cage-layered poultry house. The mesh bags hanging from the rafters contained the parasitoid wasp Muscidifurax raptorellus for release as augmentative biological control agents of house flies.

Credits: Phillip E. Kaufman, UF/IFAS

Alternatively, Carcinops pumilio that have an active and sufficient food source tend not to fly and disperse away from an area (Achiano and Giliomee 2008). These trapping strategies for augmentative biological control can both be employed in different situations. Poultry houses with newly cleaned manure pits may benefit from the release of blacklight captured beetles that will readily disperse throughout a facility (Kaufman et al. 2000). Beetles captured with attractant based traps should be released in areas of the poultry house with already active fly population growth for maximum effect (Kaufman et al. 2000).

Rearing Carcinops pumilio in sufficient numbers for augmentative biological control releases is not possible. The primary impediment is that these beetles attack each other at high densities (Geden and Stoffolano 1987). Adults will attack larvae (Achiano and Giliomee 2006a) and larvae will attack other larvae (Geden and Stoffolano 1987) when crowded. Laboratory colonies of Carcinops pumilio reared on artificial protein diets laid significantly fewer eggs, had a prolonged development time, and had slower rates of egg laying (Achiano and Giliomee 2006b). Carcinops pumilio can be reared on the larvae of the fruit fly Drosophila melanogaster Meigen (Achiano and Giliomee 2007).

Other beetle species commonly encountered in poultry production can affect the establishment of Carcinops pumilio as a biological control agent of house flies. For example, the establishment of Carcinops pumilio is impaired when poultry houses have a dense population of the omnivorous lesser mealworm, Alphitobius diaperinus (Panzer) (Watson et al. 2001). IPM strategies for establishing populations of Carcinops pumilio include the use of low residual pyrethrin insecticides to target adult fly populations while beetle populations increase and insecticidal treatment of the entire poultry house for Alphitobius diaperinus after removal of manure packs (Watson et al. 2001). Parasitoid wasp species that attack fly pupae, including Muscidifurax raptorellus Kogan and Legner, can be used along with Carcinops pumilio in a house fly IPM program in poultry houses (Kaufman et al. 2001b).

Carcinops pumilio can be found in some stored goods, food and animal by-products, and animal remains, where it is a predator on other insects. These beetles are associated with wheat and flour storage and production. For example, Carcinops pumilio has been reported from piles of discarded yeast in bakeries (Jennings 1900), stored grain, flour, and waste grain in granaries and flour mills (Dieuzeide and Tempère 1924; Joy 1932; Cotton and Good 1937), and wheat both in the field and storage (Cotton and Winburn 1941; Coombs and Woodroffe 1968). Similarly, Carcinops pumilio was collected in association with abandoned, rotting oil palm kernels in Nigeria (Allotey 1988). These beetles also are associated with wild animal remains and some aspects of meat processing. In particular, Carcinops pumilio has been reported from bone processing operations (Walker 1916) and glue factories (Fowler and Donisthorpe 1913; Walker 1932).

\section{Medical and Veterinary Importance}

Carcinops pumilio is considered to be a beneficial insect due to its ability to limit house fly populations in poultry production settings. Some research, however, has investigated whether beetles can be reservoirs for the bacteria Salmonella enterica (the cause of salmonellosis in humans) 
and Campylobacter species (most common bacterial cause of food poisoning in the US) (Gray et al. 1999; Skov et al. 2004). Laboratory experiments determined that Salmonellainoculated Carcinops pumilio can harbor the bacterium externally and internally for up to two weeks (Gray et al. 1999). Further experiments conducted in poultry houses suggested that beetles can be Salmonella reservoirs in these settings, but this is likely not the case for Campylobacter (Skov et al. 2004).

Carcinops pumilio cannot be raised in large enough numbers for the species to be commercially available for purchase. Unable to supplement their natural beetle populations commercially, poultry producers may be tempted to capture and move established beetles into poultry houses with lower numbers, such as facilities recently cleaned of their manure pack (Kaufman et al. 2002b). This practice should be practiced with caution due to a small risk of mechanically moving Salmonella bacteria into clean poultry houses on the beetles (Gray et al. 1999). Carcinops pumilio also has been reported as a potential intermediate host of the chicken parasitic cestode Hymenolepis carioca (Jones 1929).

\section{References}

Achiano KA, Giliomee JH. 2005. Biology of the housefly predator Carcinops pumilio (Erichson) (Coleoptera: Histeridae). BioControl 50: 899-910. (6 January 2017)

Achiano KA, Giliomee JH. 2006a. House fly predators in poultry manure and environmental factors affecting them. African Entomology 14: 349-355.

Achiano KA, Giliomee JH. 2006b. Rearing the housefly predator Carcinops pumilio (Erichson) (Coleoptera: Histeridae) on an artificial diet. African Journal of Biotechnology 5: 1161-1166. (6 January 2017)

Achiano KA, Giliomee JH. 2007. Rearing the house fly predator Carcinops pumilio (Erichson) (Coleoptera: Histeridae) using eggs and larvae of Drosophila melanogaster (Meigen) (Diptera: Drosophilidae) as prey. African Journal of Biotechnology 6: 2062-2064. (6 January 2017)

Achiano KA, Giliomee JH. 2008. Food-, temperature- and crowding mediated laboratory dispersal of Carcinops pumilio (Erichson) (Coleoptera: Histeridae), a predator of house fly (Diptera: Muscidae) eggs and larvae. African Entomology 16: 115-121.
Allotey J. 1988. A study of the insect pests in stored palm produce in Port Harcourt, Nigeria. Journal of Stored Products Research 24: 237-240. (6 January 2017)

Arriagada G. 1986. Histeridos Chilenos (Coleoptera: Histeridae). Primera parte. Revista Chilena de Entomología 14: 71-80.

Arrow GJ. 1927. Clavicornia and Lamellicornia. Insects of Samoa and Other Terrestrial Arthropoda. Part IV. Coleoptera, Fasc. 1: 35-66. (6 January 2017)

Australian National Insect Collection Database (ANICD). CSIRO. 2016. User query for Carcinops pumilio. (6 January 2017)

Barriga-Tuñon JE. 2014. Histeridae de México. Especies presentes en México de la familia Histeridae (Histeridae species from México). (6 January 2017)

Bajerlein D, Błoszyk J, Gwiazdowicz DJ, Ptaszyk J, Halliday B. 2006. Community structure and dispersal of mites (Acari, Mesostigmata) in nests of the white stork (Ciconia ciconia). Biologia, Bratislava 61: 525-530. (6 January 2017)

Bajerlein D, Matuszewski S, Konwerski S. 2011. Insect succession on carrion: Seasonality, habitat preference and residency of histerid beetles (Coleoptera: Histeridae) visiting pig carrion exposed in various forests (western Poland). Polish Journal of Entomology 59: 787-797. (6 January 2017)

Bernath RF, Kunz TH. 1981. Structure and dynamics of arthropod communities in bat guano deposits in buildings. Canadian Journal of Zoology 59: 260-270. (6 January 2017)

Bickhardt H. 1910. Histeridae. Coleopterorum Catalogus, Pars 24. W. Junk. Berlin, Germany. 137 p. (6 January 2017)

Bickhardt H. 1917. Histeridae. p. 113-302. In Wytsman P (ed.), Genera Insectorum, fasc. 166b. V. Verteneuil and L. Desmet. Brussels, Belgium. (6 January 2017)

Bills GT. 1973. Biological fly control in deep-pit poultry houses. British Poultry Science 14: 209-212.

Blackwelder RE. 1944. Checklist of the coleopterous insects of Mexico, Central America, the West Indies, and South America. Parts 1-6. United States National Museum Bulletin 185: i-xii, 1-1492. (6 January 2017)

Blackwelder RE. 1949. Studies on the dates of books on Coleoptera. I. The Coleopterists Bulletin 3: 42-46. (6 January 2017) 
Borowski J, Mazur S. 2015. Beetles (Coleoptera) of the Rogów region. Part IV - clown beetles (Histeridae) and false clown beetles (Sphaeritidae). International Letters of Natural Sciences 37: 10-17. (6 January 2017)

Bousquet Y, Laplante S. 2006. The insects and arachnids of Canada. Part 24. Coleoptera Histeridae. NRC Research Press. Ottawa, Ontario, Canada. 485 p. (6 January 2017)

Bryan Jr. EH. 1926. Coleoptera. pp. 46-49. In Bryan Jr. EH (ed.), Insects of Hawaii, Johnston Island and Wake Island. Tanager Expedition Publication No. 3. Bernice P. Bishop Museum Bulletin 31. Bernice P. Bishop Museum. Honolulu, Hawaii, United States. (6 January 2017)

California Academy of Sciences Entomology General Collection Database (CAS). 2016. User query for Carcinops pumilio. (6 January 2017)

Coombs CW, Woodroffe GE. 1968. Changes in the arthropod fauna of an experimental bulk of stored wheat. Journal of Applied Ecology 5: 563-574.

Cotton RT, Good NE. 1937. Annotated list of the insects and mites associated with stored grain and cereal products, and of their arthropod parasites and predators. United States Department of Agriculture Miscellaneous Publication No. 258: 1-81. (6 January 2017)

Cotton RT, Winburn TF. 1941. Field infestation of wheat by insects attacking it in farm storage. Journal of the Kansas Entomological Society 14: 12-16. (6 January 2017)

Dieuzeide R, Tempère G. 1924. Sur quelques insectes de entrepôts. Revue de Zoologie Agricole et de Pathologie Végétale 23: 116-119.

Erichson WF. 1834. III. Uebersicht der Histeroides der Sammlung*). p. 83-208. In Klug JCF (ed.), Jahrbücher der Insectenkunde, mit besonderer Rücksicht auf die Sammlung im Königl. Museum zu Berlin. Volume 1. T. C. F. Enslin. Berlin, Germany. 296 p. (6 January 2017)

Fletcher MG, Axtell RC, Stinner RE, Wilhoit LR. 1991. Temperature-dependent development of immature Carcinops pumilio (Coleoptera: Histeridae), a predator of Musca domestica (Diptera: Muscidae). Journal of Entomological Science 26: 99-108.

Florida Museum of Natural History (FLMNH). 2016. UF Bat Colony. (6 January 2017)
Fowler WW, Donisthorpe H St. J. 1913. The Coleoptera of the British Islands. A descriptive account of the families, genera, and species indigenous to Great Britain and Ireland with notes as to localities, habitats, etc. Volume 6 (Supplement). Lovell Reeve and Co. Ltd. London, United Kingdom. 351 p. +20 pl. (6 January 2017)

Frost SW, Dietrich H. 1929. Coleoptera taken from baittraps. Annals of the Entomological Society of America 22: 427-437.

Ganglbauer L. 1899. Die Käfer von Mitteleuropa. Die Käfer der österreichisch-ungarischen Monarchie, Deutschlands, der Schweiz, sowie des französsichen und italienischen Alpengebietes. Volume 3. Carl Gerold's Sohn. Vienna, Austria. 1046 p. (6 January 2017)

Geden CJ, Axtell RC. 1988. Predation by Carcinops pumilio (Coleoptera: Histeridae) and Macrocheles muscaedomesticae (Acarina: Macrochelidae) on the house fly (Diptera: Muscidae): Functional response, effects of temperature, and availability of alternative prey. Environmental Entomology 17: 739-744. (6 January 2017)

Geden CJ, Stoffolano Jr. JG. 1987. Succession of manure arthropods at a poultry farm in Massachusetts, USA, with observations on Carcinops pumilio (Coleoptera: Histeridae) sex ratios, ovarian condition, and body size. Journal of Medical Entomology 24: 212-220.

Geden CJ, Stoffolano Jr. JG, Elkinton JS. 1987. Prey-mediated dispersal behavior of Carcinops pumilio (Coleoptera: Histeridae). Environmental Entomology 16: 415-419.

Gielis C, Nunen F van, Solleveld P. 2014. De insectenfauna van enkele vogelnestkasten [in Dutch]. Entomologische Berichten 74: 81-88. (6 January 2017)

Gemminger E von, Harold B. 1868. Catalogus coleopterorum hosque descriptorum synonymicus et systematicus. Volume 3. H. Gummi. Munich, Germany. pp. 753-983. (6 January 2017)

Global Biodiversity Information Facility (GBIF). 2012. User query for Carcinops pumilio. (6 January 2017)

Gray JP, Maddox CW, Tobin PC, Gummo JD, Pitts CW. 1999. Reservoir competence of Carcinops pumilio for Salmonella enteritidis (Eubacteriales: Enterobacteriaceae). Journal of Medical Entomology 36: 888-891. (6 January 2017) 
Hågvar S. 1975. Coleoptera in nests of birds of prey. Norwegian Journal of Entomology 22: 135-142. (6 January 2017)

Hinton HE. 1945. The Histeridae associated with stored products. Bulletin of Entomological Research 35: 309-340.

Hinton JL, Moon RD. 2003. Arthropod populations in high-rise, caged-layer houses after three manure cleanout treatments. Journal of Economic Entomology 96: 1352-1361. (6 January 2017)

Jennings FB. 1900. Carcinops 14-striata Steph., in a London bakehouse. The Entomologist's Monthly Magazine 36: 43-44. (6 January 2017)

Jones MF. 1929. p. 224. In Society Proceedings of The American Society of Parasitologists. The Journal of Parasitology 15: 216-224. (6 January 2017)

Joy NH. 1932. Coleoptera from a granary at Reading. The Entomologist's Monthly Magazine 68: 85.

Kaufman PE, Long SJ, Rutz DA, Glenister CS. 2000. Preyand density-mediated dispersal in Carcinops pumilio (Coleoptera: Histeridae), a predator of house fly (Diptera: Muscidae) eggs and larvae. Journal of Medical Entomology 37: 929-932. (6 January 2017)

Kaufman PE, Long SJ, Rutz DA, Glenister CS. 2001a. Larval production from field-collected Carcinops pumilio (Coleoptera: Histeridae) following three starvation periods. Journal of Medical Entomology 38: 278-281. (6 January 2017)

Kaufman PE, Long SJ, Rutz DA, Waldron JK. 2001b. Parasitism rates of Muscidifurax raptorellus and Nasonia vitripennis (Hymenoptera: Pteromalidae) after individual and pair releases in New York poultry facilities. Journal of Economic Entomology 94: 593-598. (6 January 2017)

Kaufman PE, Burgess M, Rutz DA, Glenister C. 2002a. Population dynamics of manure inhabiting arthropods under an integrated pest management (IPM) program in New York poultry facilities-3 case studies. Journal of Applied Poultry Research 11: 90-103. (6 January 2017)

Kaufman PE, Rutz DA, Waldron JK. 2002b. Seasonal variation in Carcinops pumilio (Coleoptera: Histeridae) dispersal and potential for suppression of dispersal behavior. Journal of Medical Entomology 39: 106-111. (6 January 2017)

Kaufman PE, Reasor C, Rutz DA, Ketzis JK, Arends JJ. 2005. Evaluation of Beauveria bassiana applications against adult house fly, Musca domestica, in commercial cagedlayer poultry facilities in New York state. Biological Control 33: 360-367. (6 January 2017)

Kolbe H. 1910. Die Coleopterenfauna der Seychellen. Nebst Betrachtungen über die Tiergeographie dieser Inselgruppe. Mitteilungen aus dem Zoologischen Museum in Berlin 5: 1-49. (6 January 2017)

Krištofík J, Mašan P, Šustek Z, Karaska D. 2009. Arthropods in the nests of lesser spotted eagle (Aquila pomarina).

Biologia, Bratislava 64: 974-980. (6 January 2017)

Lackner T, Mazur S, Newton A. 2015. Family Histeridae. pp. 76-130. In Löbl I., Löbl D (eds.), Catalogue of Palaearctic Coleoptera. Vol. 2. Hydrophiloidea - Staphylinoidea, part 1. Brill Publishers. Leiden, Netherlands and Boston, Massachusetts, United States.

Larson Z, Subramanyam B, Herrman T. 2008. Storedproduct insects associated with eight feed mills in the Midwestern United States. Journal of Economic Entomology 101: 998-1005. (6 January 2017)

Leech HB. 1983. Involuntary collecting of Carcinops pumilio (Erichson) (Coleoptera: Histeridae). The Coleopterists Bulletin 37: 388. (6 January 2017)

Legner EF, Olton GS. 1970. Worldwide survey and comparison of adult predator and scavenger insect populations associated with domestic animal manure where livestock is artificially congregated. Hilgardia 40: 225-266. (6 January 2017)

Lewis G. 1905. A systematic catalogue of Histeridae. Taylor and Francis. London, United Kingdom. 81 p. (6 January 2017)

Linder W. 1967. Ökologie und Larvalbiologie einheimischer Histeriden. Zeitschrift für Morphologie und Ökologie der Tiere 59: 341-380. (6 January 2017)

Louisiana State Arthropod Museum (LSAM). 2016. Online specimen database. http://data.lsuinsects.org/. (6 January 2017)

Lundyshev DS. 2015. Beetles (Insecta, Coleoptera) - the inhabitants of the nests of birds of prey (order Accipitriformes and Falconiformes) in Belarus [in Russian]. General Biology 3: 67-74. (6 January 2017) 
Majka CG, Klimaszewski J, Lauff RF. 2006. New Coleoptera records from owl nests in Nova Scotia, Canada. Zootaxa 1194: 33-47. (6 January 2017)

Marseul SA de. 1855. Essai monographique sur la famille des Histérides. (Suite) (1). Annales de Societé Entomologique de France, Série 3: 83-165. (6 January 2017)

Marseul SA de. 1862. Supplément a la Monographie des Histérides. Annales de Societé Entomologique de France, Série 3: 581-720, + 13 pl. (6 January 2017)

Mazur S. 1997. A world catalogue of the Histeridae (Coleoptera: Histeroidea). Genus: International Journal of Invertebrate Taxonomy (Supplement). Polish Taxonomical Society. Wroclaw, Poland. 373 p.

Merkl O, Bagyura J, Rózsa L. 2004. Insects inhabiting Saker (Falco cherrug) nests in Hungary. Ornis Hungarica 14: 1-4. (6 January 2017)

Méquignon A 1944 [labeled 1943]. Notes diverses sur des Coléoptères de France. Bulletin de la Société Entomologique de France 48: 159-162.

Morgan PB, Patterson RS, Weidhass DE. 1983. A life history study of Carcinops pumilio Erichson (Coleoptera: Histeridae). Journal of the Georgia Entomological Society 18: 353-359.

Mullens BA, Hinkle NC, Szijj CE. 1996. Impact of alternating manure removal schedules on pest flies (Diptera: Muscidae) and associated predators (Coleoptera: Histeridae, Staphylinidae; Acarina: Macrochelidae) in caged-layer poultry manure in Southern California. Journal of Economic Entomology 89: 1406-1417. (6 January 2017)

Ong S-Q, Ahmad H, Jaal Z, Rus AC. 2016. Comparative effectiveness of insecticides for use against the house fly (Diptera: Muscidae): determination of resistance levels on a Malaysian Poultry farm. Journal of Economic Entomology 109: 352-359. (6 January 2017)

Peck SB. 2005. A checklist of the beetles of Cuba with data on distributions and bionomics (Insecta: Coleoptera). Arthropods of Florida and Neighboring Land Areas 18: 1-241. (6 January 2017)

Peck SB, Thomas MC. 1998. A distributional checklist of the beetles (Coleoptera) of Florida. Arthropods of Florida and Neighboring Land Areas 16: 1-180. (6 January 2017)
Penati F. 2009. An updated catalogue of Histeridae (Coleoptera) of Sardinia, with faunistic, zoogeographical, ecological and conservation remarks. p. 197-280. In Cerretti P, Mason F, Minelli A, Nardi G, Whitmore D (eds.), Research on the terrestrial arthropods of Sardinia (Italy). Zootaxa 2318: 1-602. (6 January 2017)

Pfeiffer DG, Axtell RC. 1980. Coleoptera of poultry manure in caged-layer houses in North Carolina. Environmental Entomology 9: 21-28. (6 January 2017)

Propp GD, Morgan PB. 1985. Mortality of eggs and firststage larvae of the house fly, Musca domestica L. (Diptera: Muscidae), in poultry manure. Journal of the Kansas Entomological Society 58: 442-447. (6 January 2017)

Redtenbacher L. 1858. Fauna Austriaca. Die Käfer. Second Edition. Carl Gerold's Sohn. Vienna, Austria. 1017 p. (6 January 2017)

Reitter E. 1909. Fauna Germanica. Die Käfer des Deutschen Reiches. Volume 2. K. G. Lutz. Stuttgart, Germany. 388 p. (6 January 2017)

Retamales J, Vivallo F, Robeson J. 2011. Insects associated with chicken manure in a breed poultry farm of central Chile. Archivos de Medicina Veterinaria 43: 79-83. (6 January 2017)

Roy L, Bouvier J-C, Lavigne C, Galès M, Buronfosse T. 2013. Impact of pest control strategies on the arthropodofauna living in bird nests built in nestboxes in pear and apple orchards. Bulletin of Entomological Research 103: 458-465. (6 January 2017)

Rueda LM, Axtell RC. 1997. Arthropods in litter of poultry (broiler chicken and turkey) houses. Journal of Agricultural Entomology 14: 81-91.

Seymour RC, Campbell JB. 1993. Predators and parasitoids of house flies and stable flies (Diptera: Muscidae) in cattle confinements in west central Nebraska. Environmental Entomology 22: 212-219.

Scott H. 1913. Reports of the Percy Sladen Trust Expedition to the Indian Ocean in 1905, under the leadership of Mr. J. Stanley Gardiner, M. A. Volume 5. No. X. Coleoptera: Hydrophilidae, Histeridae. The Transactions of the Linnean Society of London, Second Series, Zoology 16: 193-235. (6 January 2017) 
Skov MN, Spencer AG, Hald B, Petersen L, Nauerby B, Cartensen B, Madsen M. 2004. The role of litter beetles as potential reservoir for Salmonella enterica and thermophilic Campylobacter spp. between broiler flocks. Avian Diseases 48: 9-18. (6 January 2017)

Stephens JF. 1835. Appendix, in part, to Illustrations of British Entomology; or a synopsis of indigenous insects; containing their generic and specific distinctions; with an account of their metamorphoses, times of appearance, localities, food, and economy, as far as predictable. Mandibulata 5. Baldwin and Cradock. London, United Kingdom. pp. 369-477. (6 January 2017)

Takahashi K, Ohbayashi T, Sota N. 2000. Investigation of stored-product insect pests and their natural enemies in Chichijima Island, Ogasawara (Bonin), Japan [in Japanese]. Japanese Journal of Entomology (New Series) 3: 97-103.

Taylor RL. 1928. The arthropod fauna of coniferous leaders weeviled by Pissodes strobe (Peck). Psyche 35: 217-225. (6 January 2017)

Thompson PH. 1966. Arthropods from nests of the house sparrow. Proceedings of the Entomological Society of Washington 68: 44-48. (6 January 2017)

Tishechkin AK. 2010a. Record of two species of Histeridae new to the North American Fauna, Hypocacculus metallescens (Erichson) and Atholus confinis (Erichson), in Florida. The Coleopterists Bulletin 64: 287-288. (6 January 2017)

Tishechkin AK. 2010b. Histerid beetles (Coleoptera: Histeridae) of Louisiana. Louisiana State Arthropod Museum. Updated February 2010. (6 January 2017)

Tobin PC, Pitts CW. 1999. Flotation methods for extracting insects from poultry manure samples. Journal of Medical Entomology 36: 121-123. (6 January 2017)

University of Hawaii Insect Museum Online Database: Coleoptera (UHIM). 2011. http://www.ctahr.hawaii.edu/ insectmuseum/holdings/Coleoptera_revised_2010.htm. (25 August 2016)

Walker JJ. 1916. Occurrence of Somotrichus (Lebia) elevates F., in Cheshire. The Entomologist's Monthly Magazine 52: 203-204.

Walker JJ. 1932. An annotated list of the Coleoptera of the Isle of Sheppey. Transactions of the Entomological Society of the South of England 7: 81-140.
Watson DW, Kaufman PE, Rutz DA, Glenister CS. 2001. Impact of the darkling beetle Alphitobius diaperinus (Panzer) on establishment of predaceous beetle Carcinops pumilio (Erichson) for Musca domestica control in caged-layer poultry houses. Biological Control 20: 8-15.

Wenzel RL. 1955. The histerid beetles of New Caledonia (Coleoptera: Histeridae). Fieldiana: Zoology 37: 601-634.

Whitaker Jr. JO, Clem P, Munsee JR. 1991. Trophic structure of the community in the guano of the evening bat Nycticeius humeralis in Indiana. The American Midland Naturalist 126: 392-398. (6 January 2017)

Wollaston TV. 1857. Catalogue of the Coleopterous Insects of Madeira in the Collection of the British Museum.

Trustees of the British Museum. London, United Kingdom. 234 p. (6 January 2017)

Wollaston TV. 1864. Catalogue of the Coleopterous Insects of the Canaries in the Collection of the British Museum. Trustees of the British Museum. London, United Kingdom. 648 p. (6 January 2017)

Wollaston TV. 1865. Coleoptera Atlantidum, being an Enumeration of the Coleopterous Insects of the Madeiras, Salvages, and Canaries. John van Voorst. London, United Kingdom. 526 p. [Appendix and Index paginated separately]. (6 January 2017)

Zhang Y-J, Zhou H-Z. 2007. Taxonomy of the tribe Paromalini Reitter (Coleoptera: Histeridae, Dendrophilinae) from China. Zootaxa 1544: 1-40. 
Table 1. Country-level locality records for Carcinops pumilio. Additional state-level records are provided when available for geographically large countries or countries with overseas or island territories. Some state-level records for the US are based on specimen data from the Florida State Collection of Arthropods (FSCA), Gainesville, FL.

\begin{tabular}{|c|c|}
\hline Country & Selected References and Sources of Data \\
\hline Albania & Lackner et al. 2015 \\
\hline Algeria & Lackner et al. 2015 \\
\hline Andorra & Lackner et al. 2015 \\
\hline Argentina & Blackwelder 1944; Arriagada S. 1986 \\
\hline $\begin{array}{l}\text { Australia: Capital Territory, New South Wales, } \\
\text { Northern Territory, Queensland, South Australia, } \\
\text { Victoria, Western Australia }\end{array}$ & GBIF 2012; ANICD 2016 \\
\hline Austria & Redtenbacher 1858; GBIF 2012; Lackner et al. 2015 \\
\hline Belarus & Lundyshev 2015; Lackner et al. 2015 \\
\hline Belgium & GBIF 2012; Lackner et al. 2015 \\
\hline Bosnia and Herzegovina & Lackner et al. 2015 \\
\hline Bulgaria & Lackner et al. 2015 \\
\hline $\begin{array}{l}\text { Canada: Nova Scotia, New Brunswick, Newfoundland } \\
\text { and Labrador, Quebec, Ontario, Manitoba, } \\
\text { Saskatchewan, Alberta, British Columbia }\end{array}$ & Bousquet and Laplante 2006 \\
\hline Chile & Legner and Olton 1970; Arriagada S. 1986; Retamales et al. 2011 \\
\hline Croatia & Lackner et al. 2015 \\
\hline Cuba (speculation in literature) & Peck and Thomas 1998; Peck 2005 \\
\hline Cyprus & Lackner et al. 2015 \\
\hline Czech Republic & Lackner et al. 2015 \\
\hline Denmark & Skov et al. 2004; Lackner et al. 2015 \\
\hline Egypt & Erichson 1834; Lackner et al. 2015 \\
\hline England & Stephens 1835; Jennings 1900; GBIF 2012; Lackner et al. 2015 \\
\hline Estonia & GBIF 2012; Lackner et al. 2015 \\
\hline Finland & GBIF 2012; Lackner et al. 2015 \\
\hline France: mainland and New Caledonia & Marseul 1862; Wenzel 1955; GBIF 2012; Lackner et al. 2015 \\
\hline Germany & GBIF 2012; Lackner et al. 2015 \\
\hline Georgia & Lackner et al. 2015 \\
\hline Greece & Lackner et al. 2015 \\
\hline Guinea-Bissau & GBIF 2012 \\
\hline Hungary & Merkl et al. 2004; Lackner et al. 2015 \\
\hline Ireland & Lackner et al. 2015 \\
\hline Israel & Legner and Olton 1970 \\
\hline Italy & Penati 2009; Lackner et al. 2015 \\
\hline Japan & Takahashi et al. 2000; GBIF 2012; Lackner et al. 2015 \\
\hline Latvia & Lackner et al. 2015 \\
\hline Libya & Lackner et al. 2015 \\
\hline Liechtenstein & Lackner et al. 2015 \\
\hline Lithuania & Lackner et al. 2015 \\
\hline Luxembourg & Lackner et al. 2015 \\
\hline Macedonia & Lackner et al. 2015 \\
\hline Malaysia & Ong et al. 2016 \\
\hline Malta & Lackner et al. 2015 \\
\hline Mexico (online checklist) & Barriga-Tuñon 2014 \\
\hline
\end{tabular}




\begin{tabular}{|c|c|}
\hline Country & Selected References and Sources of Data \\
\hline Moldova & Lackner et al. 2015 \\
\hline Montenegro & Lackner et al. 2015 \\
\hline Morocco & Lackner et al. 2015 \\
\hline the Netherlands & GBIF 2012; Gielis et al. 2014; Lackner et al. 2015 \\
\hline New Zealand (citizen science data) & Legner and Olton 1970; iNaturalist.org \\
\hline Nigeria & Allotey 1988 \\
\hline Norway & Hågvar 1975; GBIF 2012; Lackner et al. 2015 \\
\hline $\begin{array}{l}\text { People's Republic of China: Beijing, Hebei, } \\
\text { Heilongjiang, Shanxi, Yunnan }\end{array}$ & Zhang and Zhou 2007; Lackner et al. 2015 \\
\hline Poland & Bajerlein et al. 2006, 2011; GBIF 2012; Borowski and Mazur 2015; Lackner et al. 2015 \\
\hline Portugal: mainland, Azores, and Madeira Archipelago & Wollaston 1857, 1865; GBIF 2012; Lackner et al. 2015 \\
\hline Republic of China (Taiwan) & Zhang and Zhou 2007; Lackner et al. 2015 \\
\hline Romania & Lackner et al. 2015 \\
\hline Russia & Lackner et al. 2015 \\
\hline Samoa & Arrow 1927 \\
\hline Serbia & Lackner et al. 2015 \\
\hline Seychelles & Scott 1913 \\
\hline Slovakia & Krištofík et al. 2009; Lackner et al. 2015 \\
\hline Slovenia & Lackner et al. 2015 \\
\hline South Africa & Achiano and Giliomee 2006a \\
\hline South Korea & Lackner et al. 2015 \\
\hline Spain: The Canary Islands and mainland & Wollaston 1864, 1865; GBIF 2012; Lackner et al. 2015 \\
\hline Sweden & GBIF 2012; Lackner et al. 2015 \\
\hline Switzerland & Lackner et al. 2015 \\
\hline Tunisia & Lackner et al. 2015 \\
\hline Turkey & Lackner et al. 2015 \\
\hline Ukraine & Lackner et al. 2015 \\
\hline $\begin{array}{l}\text { United States: Arizona, California, Colorado, Florida, } \\
\text { Georgia, Hawaii, Illinois (FSCA), Indiana, Kansas, } \\
\text { Louisiana, Maryland, Massachusetts, Michigan (FSCA), } \\
\text { Minnesota, Nebraska, Nevada, New Hampshire, } \\
\text { New Mexico, New York, North Carolina, Oregon, } \\
\text { Pennsylvania, South Carolina, Tennessee (FSCA), } \\
\text { Texas, Utah, Washington, Wisconsin (probably also } \\
\text { lowa, Missouri, and Oklahoma based on Larson et al. } \\
\text { [2008]) }\end{array}$ & $\begin{array}{l}\text { Frost and Dietrich 1929; Cotton and Winburn 1941; Thompson 1966; Legner and Olton } \\
\text { 1970; Pfeiffer and Axtell 1980; Bernath and Kunz 1981; Leech 1983; Propp and Morgan } \\
\text { 1985; Geden et al. 1987; Whitaker et al. 1991; Seymour and Campbell 1993; Mullens et } \\
\text { al. 1996; Rueda and Axtell 1997; Tobin and Pitts 1999; Hinton and Moon 2003; Larson } \\
\text { et al. 2008; Tishechkin 2010a, b; UHIM 2011; LSAM 2016; CAS } 2016\end{array}$ \\
\hline Uzbekistan & Lackner et al. 2015 \\
\hline
\end{tabular}


Table 2. Bird nest associations of Carcinops pumilio in North America.

\begin{tabular}{|l|l|l|l|}
\hline \multicolumn{1}{|c|}{ Bird Common Name } & \multicolumn{1}{c|}{ Bird Scientific Name } & \multicolumn{1}{c|}{ Country: State or Province } & References \\
\hline Northern saw-whet owl & Aegolius acadicus (Gmelin) & Canada: Nova Scotia & Majka et al. 2006 \\
\hline House sparrow & Passer domesticus (Linnaeus) & US: Wisconsin & Thompson 1966 \\
\hline
\end{tabular}

Table 3. Bird nest associations of Carcinops pumilio in Europe.

\begin{tabular}{|c|c|c|c|}
\hline Bird Common Name & Bird Scientific Name & Country: State, Region, or County & References \\
\hline Great tit & Parus major Linnaeus & France: Vaucluse & Roy et al. 2013 \\
\hline Tawny owl & Strix aluco Linnaeus & Norway: Akershus & Hågvar 1975 \\
\hline Long-eared owl & Asio otus (Linnaeus) & Norway: Akershus & Hågvar 1975 \\
\hline Common kestrel & Falco tinnunculus Linnaeus & Norway: Akershus & Hågvar 1975 \\
\hline Common buzzard & Buteo buteo (Linnaeus) & Norway: Akershus; Belarus & Hågvar 1975; Lundyshev 2015 \\
\hline White stork & Ciconia ciconia (Linnaeus) & Poland & Bajerlein et al. 2006 \\
\hline Lesser spotted eagle & Clanga pomarina (Brehm) & Slovakia: Orava; Belarus & Krištofík et al. 2009; Lundyshev 2015 \\
\hline Greater spotted eagle & Clanga clanga (Pallas) & Belarus & Lundyshev 2015 \\
\hline Black kite & Milvus migrans (Boddaert) & Belarus & Lundyshev 2015 \\
\hline Northern goshawk & Accipiter gentilis (Linnaeus) & Belarus & Lundyshev 2015 \\
\hline Barn owl & Tyto alba (Scopoli) & Netherlands & Gielis et al. 2014 \\
\hline Saker falcon & Falco cherrug Gray & Hungary: Heves and Borsod-Abaúj-Zemplén & Merkl et al. 2004 \\
\hline
\end{tabular}

